\title{
ANALISIS KEMAMPUAN STEAM BERBASIS GENDER PADA MATERI ARCHAEBACTERIA DAN EUBACTERIA SISWA
}

\author{
Hasruddin $^{1}$, Evi Lestari ${ }^{2}$ \\ ${ }^{1,2}$ Program Studi Pendidikan Biologi, FMIPA, Universitas Negeri Medan, Jl. Williem Iskandar Psr. V Medan Estate, \\ Medan, Indonesia, 20221 \\ *Korespondensi Author: hasruddin_lbsmdn@unimed.ac.id
}

\section{INFO ARTIKEL}

Riwayat artikel:

Diterima 27 Febuari 2020

Revisi 20 November 2020

Dipublikasikan 22 November 2020

Kata kunci:

Archaebacteria, Eubacteria, Gender, STEAM

\section{ABSTRAK}

Penelitian bertujuan mengetahui gambaran kemampuan STEAM siswa materi Archaebacteria dan Eubacteria berbasis gender di SMAN 2 Percut Sei Tuan dan mengetahui pandangan siswa terhadap pembelajaran materi Archaebacteria dan Eubacteria dengan pendekatan saintifik. Metode deskriptif dalam penelitian menggunakan populasi seluruh siswa kelas X IPA. Sampel terdiri dari 50 orang siswa laki-laki dan 50 orang siswa perempuan ditentukan secara random sampling. Pengumpulan data menggunakan angket dan 10 soal essay. Data dianalisis menggunakan teknik prosentase dan perbedaan kemampuan gender dilakukan uji t pada taraf signifikansi 5\% berbantuan SPSS 24.0. Hasil penelitian menunjukkan kemampuan science siswa perempuan $(78,67 \%)>$ siswa laki-laki $(47,07 \%)$, th $>\mathrm{tt}, \mathrm{p} 0,05$. Kemampuan technology pada siswa perempuan $(61,33 \%)>$ siswa laki-laki $(47,00 \%)$, -th $>$-tt p 0,05. Kemampuan engineering siswa perempuan $(64,29 \%)>$ siswa laki-laki $(50,00 \%)$, th $>\mathrm{tt}, \mathrm{p} 0,05$. Kemampuan arts siswa perempuan $(72,40 \%)>$ siswa laki-laki $(65,00 \%)$, th $>\mathrm{tt}, \mathrm{p} 0,05$. Kemampuan mathematics siswa perempuan $(65,75 \%)>$ siswa laki-laki $(56,25 \%)$, th $>t t, p$ 0,05 . Kemampuan STEAM siswa terdapat perbedaan, siswa perempuan $(70,60 \%)$ sedangkan siswa laki-laki $(53,00 \%)$, -th > -tt, p 0,05. Pandangan siswa perempuan lebih positif dibandingkan siswa laki-laki pada pembelajaran materi Archaebacteria dan Eubacteria dengan pendekatan saintifik.

\section{ABSTRACT}

This research aims to know the STEAM ability of students based on Archaebacteria and Eubacteria based on gender in SMAN 2 Percut Sei Tuan, to find out students' views on learning Archaebacteria and Eubacteria material with a scientific approach. The descriptive method in the study used a population of all students of class $X$ Natural Sciences. The sample consisted of 50 male students and 50 female students by random sampling. Data collection using questionnaires and 10 essay questions. Data were analyzed using percentage techniques and differences in gender ability were performed t-test at a significance level of $5 \%$ aided by SPSS 24.0. The results showed the science ability of female students $(78.67 \%)>$ male students $(47.07 \%)$, th> tt, p 0.05. The ability of technology in female students (61.33\%)> male students (47.00\%), -th> -tt p 0.05. Engineering ability of female students $(64.29 \%)>$ male students $(50.00 \%), t h>t t, p 0.05$. Arts ability of female students $(72.40 \%)>$ male students $(65.00 \%)$, th>tt, p 0.05 . Mathematical ability of female students $(65.75 \%)>$ male students $(56.25 \%)$, $\mathrm{th}>\mathrm{tt}, \mathrm{p} 0.05$. There are differences in the STEAM ability of students, female students $(70.60 \%)$ while male students $(53.00 \%)$, - th> -tt, p 0.05. The views of female students are more positive than male students in learning Archaebacteria and Eubacteria material with a scientific approach. 
How to Cite:

Hasruddin \& Lestari, E. (2020). Analisis Kemampuan STEAM Berbasis Gender pada Materi Archaebacteria dan Eubacteria Siswa. Jurnal Pelita Pendidikan, 8(3), 181-188.

\section{PENDAHULUAN}

Materi pelajaran biologi pada dasarnya berisi konsep, prinsip, dan proses, begitu pula pada materi Archaebacteria dan Eubacteria yang diajarkan di tingkat Sekolah Menengah Atas (SMA). Handayani, dkk (2016) menyatakan bahwa pembelajaran sains termasuk biologi dipelajari sebagai ilmu yang terdiri dari hands on, minds on, dan hearts on agar pembelajaran biologi berlangsung sesuai dengan ruhnya sebagai sains. Hal yang sependapat juga dikemukakan oleh Apriliana dkk (2018) bahwa pembelajaran sains perlu ditekankan pada kemampuan science, technology, engineering, arts, dan mathematics (STEAM). Selanjutnya Apriliana dkk (2018) menyatakan bahwa STEAM merupakan pengembangan dari STEM yang menambahkan unsur seni (arts) dalam proses pembelajaran.

Pemahaman siswa terhadap materi biologi berkaitan dengan STEAM, merupakan tuntutan dari pentingnya mempersiapkan siswa pada era revolusi industi 4.0, dimana kemampuan dasar siswa tidak hanya seperti selama ini hanya kemampuan sains. Saat ini diperlukan pemahaman yang terintegrasi antara kemampuan sains, teknologi, rekayasa, seni, dan matematika. Menurut Arikunto (2005) masih banyak siswa mengalami kesulitan dalam mempelajari mata pelajaran biologi, terutama dalam memahami konsep-konsep dan prinsip-prinsip biologi sebagai sains, belum lagi pemahaman berkaitan dengan teknologi, rekayasa, seni, dan kemampuan matematika.

Saat ini pembelajaran biologi di SMA sudah menerapkan kurikulum 2013 dengan pendekatan saintifik. Pendekatan saintifik yang diimplementasikan di sekolah dengan menggunakan pola 5M, yaitu Mengamati, Menanya, Mengasosiasikan, Menyimpulkan, dan Mengkomunikasikan. Melalui pola $5 \mathrm{M}$ ini diharapkan siswa mampu bekerja secara ilmiah karena pada dasarnya dengan menerapkan pola $5 \mathrm{M}$ ini siswa dilatih untuk melakukan metode ilmiah (Surachman dkk, 2014). Pendekatan saintifik juga memberikan peluang untuk berkembangnya pemahaman siswa secara terintegrasi untuk dapat memiliki kemampuan sains, teknologi, rekayasa, seni, dan kemampuan matematika.

Namun, sejauh ini masih belum dilakukan secara ril, penerapan pendekatan saintifik dengan pola $5 \mathrm{M}$ dalam mengintegrasikan kemampuan sains, teknologi, rekayasa, seni, dan matematika. Menurut Rini (2017), bahwa faktor gender menjadi bahasan utama yang menarik untuk diteliti dalam meningkatkan mutu pada proses pembelajaran sains-biologi. Hasil penelitian Lestari dkk (2019) ditemukan bahwa pada materi virus siswa perempuan cenderung lebih tinggi pada kemampuan teknologi, rekayasa, dan matematika, namun pada kemampuan sains, siswa laki-laki lebih tinggi daripada perempuan.Peserta didik antar gender mempunyai hasil belajar kognitif pada pemahaman konsep yang berbeda dan hasil belajar siswa laki-laki lebih rendah dibandingkan dengan kriteria ketuntasan minimum. Menurut Wahyudi (2014) hal ini disebabkan proses pembelajaran yang monoton di kelas dan adanya perbedaan psikologis dan fisiologis berbeda antar gender yang dapat mempengaruhi proses pembelajaran dan hasil belajar.

Hasil wawancara kepada guru biologi yang mengajar di kelas X SMAN 2 Percut Sei Tuan, bahwa mereka sudah menerapkan K13 dengan menggunakan pendekatan saintifik pola $5 \mathrm{M}$ dalam proses pembelajaran biologi. Pengukuran biologi sebagai sains sudah lazim dilakukan terutama untuk mengukur kemampuan kognitif siswa. Namun disadari bahwa pengukuran berkaitan dengan dengan teknologi, rekayasa, seni, dan kemampuan matematika siswa belum dilakukan secara sistemik. Beberapa hasil penelitian Purwanti (2013); Salmina dan Nisa (2017) bahwa kemampuan siswa perempuan lebih baik dari pada laki-laki, karena lebih sering ditemukan siswa perempuan lebih tekun dalam belajar.

Pada dasarnya kemampuan siswa yang diharapkan dalam proses pembelajaran biologi pada era revolusi industri 4.0 yaitu kemampuan literasi, keterampilan berpikir kritis, kemampuan memecahkan masalah, dan berpikir kreatif siswa (Firman, 2016). Selanjutnya, kemampuan siswa juga diharapkan memiliki kemampuan sains, menguasai teknologi, memahami rekayasa, dan penguasaan matematika yang tinggi (Aprilian, dkk, 2018). Siswa juga harus memiliki keterampilan berpikir tingkat tinggi (Hasruddin, 2018), juga dengan memiliki rasa seni (arth) dalam memahami sains termasuk biologi (Buinicontro, 2018). Berdasarkan uraian permasalahan tersebut, dipandang perlu melakukan penelitian dengan menganalisis kemampuan STEAM yang saat ini 
dibutuhkan untuk mengikuti era abad 21 dengan membandingkan peserta didik berbasis gender antara laki-laki dan perempuan, karena memiliki faktorpsikologis, fisiologis, dan hasil belajar yang berbeda.

\section{METODE PENELITIAN}

Penelitian ini merupakan penelitian deskriptif kuantitatif yang mengumpulkan data dengan cara pengisian angket dan 10 butir soal essai. Sampel penelitian ini adalah 100 orang siswa kelas $X$ SMAN 2 Percut Sei Tuan yang terdiri dari, 50 orang siswa laki-laki dan 50 orang siswa perempuan yang ditentukan secara random sampling. Penelitian ini dilaksanakan pada bulan Desember 2019-Februari 2020 di SMAN 2 Percut Sei Tuan pada kelas X IPA1 sampai denganX IPA5. Angket yang digunakan dalam penelitian ini disusun berdasarkan 5 indikator, yaitu Archaebacteria dan Eubacteria dipandang sebagai sains, Archaebacteria dan Eubacteria dalam kajian teknologi, Archaebacteria dan Eubacteria dalam kajian rekayasa, gambargambar Archaebacteria dan Eubacteria dipandang dari unsur seni, dan Archaebacteria dan Eubacteria disajikan dalam sentuhan matematika. Data hasil penelitian dianalisis menggunakan teknik prosentase dan untuk membedakan kemampuan gender dilakukan uji $\mathrm{t}$ (independent sample t-test) berbantuan SPSS 24.0 for windows.

\section{HASIL DAN PEMBAHASAN}

Berdasarkan hasil penelitian kemampuan STEAM di kelas X IPA SMAN 2 Percut Sei Tuan, diperoleh kemampuan STEAM berdasarkan gender pada materi Archaebacteria dan Eubacteria. Perbandingan nilai rata-rata kemampuan STEAM siswa pada materi Archaebacteria dan Eubacteria diperoleh seperti pada Gambar 1.

Berdasarkan diagram batang pada Gambar 1, bahwa kemampuan science siswa perempuan lebih tinggi dibandingkan siswa laki-laki, yakni sebesar $78,67 \%$ sedangkan siswa laki-laki memperoleh 47,07\%. Kemampuan technology siswa perempuan lebih tinggi dibandingkan siswa laki-laki, yakni sebesar $61,33 \%$ sedangkan siswa laki-laki memperoleh 47,00\%. Kemampuan engineering siswa perempuan lebih tinggi dibandingkan siswa laki-laki, yakni sebesar $64,29 \%$

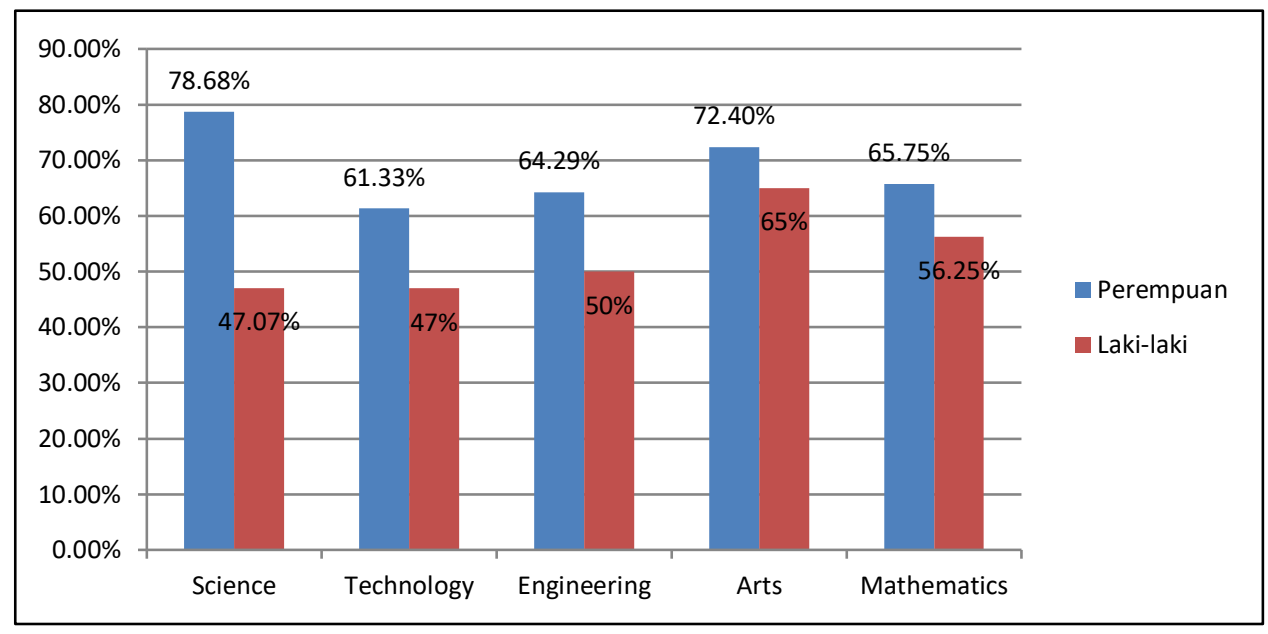

Gambar 1. Perbandingan Rata-rata Kemampuan STEAM Siswa

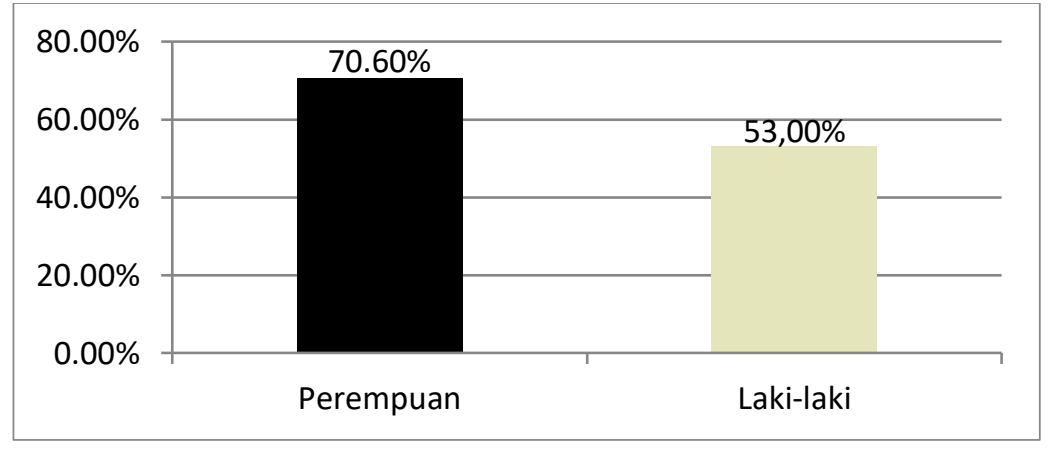

Gambar 2. Perbandingan Nilai Keseluruhan Kemampuan STEAM Siswa 
sedangkan siswa laki-laki memperoleh 50,00\%. Kemampuan arts siswa perempuan lebih tinggi dibandingkan siswa laki-laki, yakni sebesar $72,40 \%$ sedangkan siswa laki-laki memperoleh 65,00\%. Kemampuan mathematics siswa perempuan lebih tinggi dibandingkan siswa laki-laki, yakni sebesar $65,75 \%$ sedangkan siswa laki-laki memperoleh $56,25 \%$. Sedangkan perbandingan nilai keseluruhan kemampuan STEAM terdapat pada Gambar 2.

Berdasarkan hasil diagram pada Gambar 2, dapat dinyatakan bahwa kemampuan STEAM siswa perempuan lebih tinggi dibandingkan kemampuan STEAM siswa laki-laki atau dengan kata lain siswa perempuan lebih mendominasi kemampuan STEAM seluruhnya dibandingkan siswa laki-laki.

\section{Uji t Kemampuan STEAM}

Berdasarkan uji hipotesis dengan menggunakan uji $\mathrm{t}$ pada taraf signifikansi 0,05 diperoleh hasil seperti pada Tabel 1 berikut ini.

Tabel 1. Hasil Uji t Kemampuan STEAM

\begin{tabular}{lccl}
\hline \multicolumn{1}{c}{ Variabel } & t Hitung & Sig. & \multicolumn{1}{c}{ Mean } \\
\hline Kemampuan Science & 11,410 & 0,140 & $\begin{array}{l}\text { Laki-laki }=7,06 \\
\text { Perempuan }=11,80\end{array}$ \\
\hline Kemampuan Technology & $-2,490$ & 0,455 & $\begin{array}{l}\text { Laki-laki }=2,82 \\
\text { Perempuan }=3,68\end{array}$ \\
\hline Kemampuan Engineering & 3,029 & 0,815 & $\begin{array}{l}\text { Laki-laki }=3,50 \\
\text { Perempuan }=4,50\end{array}$ \\
\hline $\begin{array}{l}\text { Kemampuan Arts } \\
\text { Kemampuan }\end{array}$ & 2,062 & 0,377 & $\begin{array}{l}\text { Laki-laki }=6,50 \\
\text { Perempuan }=7,24\end{array}$ \\
$\begin{array}{l}\text { Mathematics } \\
\text { Kemampuan STEAM }\end{array}$ & 2,324 & 0,607 & $\begin{array}{l}\text { Laki-laki }=4,50 \\
\text { Perempuan }=5,26\end{array}$ \\
\hline
\end{tabular}

Berdasarkan Tabel 1 menunjukkan bahwa terdapat perbedaan kemampuan science, technology, engineering, arts, and mathematics antara siswa perempuan dengan siswa laki-laki, dimana siswa perempuan lebih tinggi dibandingkan siswa laki-laki. Hal ini menunjukkan bahwa siswa perempuan yang paling mendominasi kemampuan STEAM secara keseluruhan pada materi Archaebacteria dan Eubacteria.

\section{Pandangan Siswa Terhadap Pendekatan Saintifik}

Untuk melihat pandangan siswa dalam pembelajaran Biologi pada materi Archaebacteria dan Eubacteria, maka diperoleh data angket siswa pada Tabel 2 berikut ini.

Tabel 2. Pandangan Siswa terhadap Penerapan Pendekatan Saintifik

\begin{tabular}{|c|c|c|c|c|c|c|c|c|c|}
\hline \multirow{3}{*}{ Pertanyaan } & \multicolumn{4}{|c|}{ Siswa Perempuan } & \multirow{3}{*}{ Pertanyaan } & \multicolumn{4}{|c|}{ Siswa Laki-laki } \\
\hline & \multicolumn{2}{|c|}{ Frekuensi } & \multicolumn{2}{|c|}{ Persentase (\%) } & & \multicolumn{2}{|c|}{ Frekuensi } & \multicolumn{2}{|c|}{ Persentase (\%) } \\
\hline & Ya & Tidak & $\mathrm{Ya}$ & Tidak & & Ya & Tidak & Ya & Tidak \\
\hline 1 & 30 & 20 & 60 & 40 & 1 & 28 & 22 & 56 & 44 \\
\hline 2 & 45 & 5 & 90 & 10 & 2 & 45 & 5 & 90 & 10 \\
\hline 3 & 40 & 10 & 80 & 20 & 3 & 37 & 13 & 74 & 26 \\
\hline 4 & 40 & 10 & 80 & 20 & 4 & 36 & 14 & 72 & 28 \\
\hline 5 & 42 & 8 & 84 & 16 & 5 & 32 & 18 & 64 & 36 \\
\hline 6 & 46 & 4 & 92 & 8 & 6 & 39 & 11 & 78 & 22 \\
\hline 7 & 33 & 17 & 66 & 34 & 7 & 26 & 24 & 52 & 48 \\
\hline 8 & 35 & 15 & 70 & 30 & 8 & 21 & 29 & 42 & 58 \\
\hline 9 & 38 & 12 & 76 & 24 & 9 & 40 & 10 & 80 & 20 \\
\hline 10 & 32 & 18 & 64 & 36 & 10 & 17 & 33 & 34 & 66 \\
\hline 11 & 30 & 20 & 60 & 40 & 11 & 27 & 23 & 54 & 46 \\
\hline
\end{tabular}


Berdasarkan Tabel 2 ditemukan bahwa siswa perempuan lebih banyak menjawab YA daripada TIDAK. Sebaliknya, siswa laki-laki lebih banyak menjawab TIDAK daripada YA. Berdasarkan hal tersebut, dapat dinyatakan bahwasiswa perempuan lebih berpandangan positif terhadap penerapan pendekatan saintifik pada pembelajaran biologi materi Achaebacteria dan Eubacteria.

Hasil penelitian ditemukan bahwa kemampuan science siswa perempuan lebih tinggi dibandingkan siswa laki-laki, yakni siswa perempuan memperoleh $78,67 \%$ dan siswa lakilaki memperoleh 47,07\%. Berdasarkan Independent Sample t-test antara gender dan kemampuan science diperoleh $\mathrm{t}$ hitung sebesar 11,410 dan nilai t tabel sebesar 1,98 dengan df 98 dan taraf signifikansi 0,140. Hal ini membuktikan bahwa t hitung $>\mathrm{t}$ tabel $(11,410>1,98)$ pada taraf signifikansi 5\%. Dengan demikian terdapat perbedaan kemampuan science antara siswa lakilaki dan siswa perempuan dimana siswa perempuan lebih tinggi dari pada laki-laki. Hasil penelitian Elliot et al (2000) bahwa di bidang sains yang menekankan pada kegiatan laboratorium yang membutuhkan partisipasi aktif bahwa nilai siswa perempuan meningkat drastis dibandingkan siswa laki-laki. Hasil penelitian Bastable (2002) ditemukan bahwa siswa perempuan cenderung memberikan upaya lebih tinggi dalam penyelesaian masalah, dimana siswa laki-laki lebih cenderung bermalas-malasan di dalam kelas ketika proses pembelajaran biologi.

Kemampuan technology siswa perempuan lebih tinggi dibandingkan siswa laki-laki, yakni siswa perempuan memperoleh $61,33 \%$ dan siswa laki-laki hanya memperoleh $47,00 \%$. Berdasarkan Independent Sample t-test antara gender dan kemampuan technology diperoleh $t$ hitung sebesar $-2,490$ dan nilai t tabel sebesar $-1,98$ (uji t 2 pihak) dengan df 98 dan taraf signifikansi 0,455 . Hal ini membuktikan bahwa -t hitung $>-t$ tabel $(-2,490>-$ 1,98) pada tarafsignifikansi 5\%. Dengan demikian terdapat perbedaan kemampuan technology antara siswa laki-laki dan siswa perempuan, dimana kemampuan technologysiswa perempuan lebih tinggi dibandingkan laki-laki. Hal ini sejalan dengan YJP (2016) menyatakan bahwa perempuan lebih berkontribusi besar terhadap sains dan teknologi dibandingkan laki-laki. Perempuan lebih mudah memiliki akses dan menguasai STI, ICT, dan STEM. Hal ini semakin menegaskan hasil penelitian Lestari dkk (2019) bahwa kemampuan teknologi siswa perempuan lebih tinggi daripada lakilaki.Hasil penelitian ini juga sejalan dengan Lestari (2010) bahwa peran perempuan dalam perkembangan teknologi informasi sudah bisa menciptakan daya saing global untuk menciptakan, menerapkan, dan menggunakannya secara maksimal di ruang publik. Lebih lanjut Lestari (2010) menyatakan bahwa perkembangan teknologi informasi mengalami akselerasi yang sangat cepat yang membuat wanita mudah dalam mengakses teknologi informasi di antaranya tingkat pendidikan, masalah bahasa, norma budaya dan sosial.

Kemampuan engineering siswa perempuan lebih tinggi dibandingkan siswa laki-laki, yakni siswa perempuan memperoleh $64,29 \%$ dan siswa laki-laki hanya memperoleh $50,00 \%$. Berdasarkan Independent Sample t-test antara gender dan kemampuan engineering diperoleh $t$ hitung sebesar 3,029 dan nilai t tabel sebesar 1,98 dengan df 98 dan taraf signifikansi 0,815. Hal ini membuktikan bahwa t hitung > t tabel $(3,029>$ $1,98)$ pada taraf signifikansi $5 \%$. Dengan demikian terdapat perbedaan kemampuan engineering antara siswa laki-laki dan siswa perempuan, dimana kemampuan engineering siswa perempuan lebih tinggi dibandingkan laki-laki. Hal ini sejalan dengan Aziz dan Mangestuti (2005) menyatakan bahwa perempuan cenderung lebih tinggi daripada laki-laki dalam hal kecerdasan intelektual, perancangan menghadapi pembelajaran, dan memiliki kreativitas yang baik. Hal yang sama juga dinyatakan oleh Kartono (1989) bahwa perempuan cenderung lebih memiliki gaya rancangan dan model berpikir yang baikdibandingkan laki-laki. Hal ini semakin menegaskan hasil penelitian Handayani dan Novianto (2004) menyatakan bahwa perempuan lebih baik dalam merencanakan sesuatu dan telah dididik untuk mengatasi persoalan-persoalan praktis dibandingkan laki-laki.

Kemampuan arts siswa perempuan lebih tinggi dibandingkan siswa laki-laki, yakni siswa perempuan memperoleh $72,40 \%$ dan siswa lakilaki hanya memperoleh $65,00 \%$. Berdasarkan Independent Sample t-test antara gender dan kemampuan arts diperoleh $\mathrm{t}$ hitung sebesar 2,062 dan nilai t tabel sebesar 1,98 dengan df 98 dan taraf signifikansi 0,377. Hal ini membuktikan bahwa t hitung $>$ t tabel $(2,062>1,98)$ pada taraf signifikansi 5\%. Dengan demikian terdapat perbedaan kemampuan arts antara siswa laki-laki dan siswa perempuan, dimana siswa perempuan memiliki kemampuan arts yang lebih tinggi dibandingkan siswa laki-laki. Hal ini sejalan dengan Cramond et al (2005) yang menyatakan bahwa perempuan memiliki kualitas dan kuantitas yang lebih tinggi pada aspek elaborasi, imajinasi dan originalitas, sedangkan laki-laki hanya menguasai pada aspek fleksibilitas. Hal ini semakin ditegaskan dalam hasil penelitian Utomo (2006) yang 
menyatakan bahwa perbedaan peran antara lakilaki dan perempuan secara gender dalam konteks perilaku berkesenian tentu saja berkaitan dengan pandangan dan nilai-nilai budaya masyarakat, dimana perempuan cenderung lebih memegang kendali yang tercermin melalui berbagai wujud karya seni, proses pengajaran, proses pertunjukan seni dan lain-lain.

Kemampuan mathematics siswa perempuan lebih tinggi dibandingkan siswa laki-laki, yakni siswa perempuan memperoleh $65,75 \%$ dan siswa laki-laki hanya memperoleh $56,25 \%$. Berdasarkan Independent Sample t-test antara gender dan kemampuan mathematics diperoleh $t$ hitung sebesar 2,324 dan nilait tabel sebesar 1,98 dengan df 98 dan taraf signifikansi 0,607. Hal ini membuktikan bahwa $\mathrm{t}$ hitung $>\mathrm{t}$ tabel $(2,324>$ $1,98)$ pada taraf signifikansi $5 \%$. Dengan demikian terdapat perbedaan kemampuan mathematics antara siswa laki-laki dan siswa perempuan, dimana siswa perempuan memiliki kemampuan matematika yang lebih tinggi dibandingkan siswa laki-laki. Hal ini sejalan dengan Salmina dan Nisa (2018) yang menyatakan kemampuan penalaran matematis siswa perempuan lebih unggul dibandingkan kemampuan penalaran matematis siswa laki-laki. Saraswati (2015) juga menegaskan bahwa hasil belajar matematika siswa perempuan lebih tinggi dibandingkan siswa laki-laki. Menurut Amin dan Suadriman (2016) matematika siswa perempuan lebih tinggi dibandingkan siswa lakilaki disebabkan oleh sikap laki-laki yang cenderung susah diatur, tidak memperhatikan pelajaran di kelas, tidak tenang dan tidak serius dalam mengerjakan soal yang diberikan dibandingkan dengan sifat siswa perempuan yang lebih rajin, memperhatikan pelajaran di kelas, tenang dan serius ketika mengerjakan soal yang diberikan.

Di sisi lain, menurut Casey et al, 2001) anak laki-laki cenderung lebih menguasai matematika dengan kinerja penyelesaian soal yang baik dibandingkan anak perempuan. Lebih lanjut Casey et al, 2001) menyatakan bahwa kemungkinan perempuan mengalami kesulitan bermatematika disebabkan oleh lingkungan sekolah. Menurut Russet (dalam Orton 1992), organisasi intra sekolah di Amerika Serikat tidak selalu mengizinkan perempuan untuk bergabung dalam kajian matematika, sehingga dorongan lebih banyak kepada anak laki-laki daripada anak perempuan. Hal ini membuat anak laki-laki selalu memimpin pelajaran matematika dibandingkan anak perempuan. Hal ini sejalan dengan penelitian Purwanti (2013) yang menyatakan bahwa pencapaian siswa laki-laki lebih tinggi dibandingkan siswa perempuan dalam pelajaran matematika yang hampir terjadi di semua negara.
Secara keseluruhan kemampuan STEAM siswa perempuan lebih tinggi dibandingkan siswa laki-laki, siswa perempuan memperoleh total nilai STEAM sebesar $70,60 \%$ sedangkan siswa laki-laki memperoleh total nilai STEAM sebesar 53,00\%. Berdasarkan Independent Sample t-test antara gender dan kemampuan STEAM diperoleh t hitung sebesar -9,683 dan nilai $t$ tabel sebesar $-1,98$ dengan df 98 dan taraf signifikansi 0,184 . Hal ini membuktikan bahwa -t hitung > -t tabel $(-9,683>$ $1,98)$ pada taraf signifikansi $5 \%$. Dengan demikian terdapat perbedaan kemampuan STEAMantara siswa laki-laki dan siswa perempuan. Siswa perempuan mendominasi kemampuan STEAM daripada siswa laki-laki. Hal ini disebabkan karena keseriusan siswa perempuan dalam menjawab instrumen pada saat diberikan dibandingkan siswa laki-laki (Amin dan Suadriman, 2016).

Kemudian Brizendine (2006) menyatakan bahwa aspek psikologis khususnya kreativitas terdapat perbedaan antara laki-laki dan perempuan yang bisa dipahami dari berbagai sudut pandang, dimana perempuan cenderung lebih mudah menerima segala kondisi dan menyelesaikannya dengan baik. Lebih lanjut Brizendine (2006) menyatakan bahwa struktur otak antara laki-laki dan perempuan yang berakibat pada perbedaan keduanya dalam cara berpikir, cara memandang sesuatu, cara berkomunikasi, yang masih dikuasai oleh perempuan. Hal ini semakin menegaskan hasil penelitian Suhendra (2008) siswa perempuan mendapatkan kenaikan yang lebih tinggi dibandingkan dengan siswa laki-laki di semua mata pelajaran di sekolah. Dengan demikian terdapat perbedaan kemampuan STEAM siswa kelas X IPA SMAN 2 Percut Sei Tuan, dimana siswa perempuan lebih unggul dibandingkan siswa laki-laki pada materi Archaebacteria dan Eubacteria.

Untuk mengetahui pandangan siswa terhadap guru Biologi dalam penerapan pendekatan santifik pada pembelajaran Biologi materiArchaebacteria dan Eubacteria digunakan Skala Thrustone untuk mengukur pandangan atau persepsi seseorang atau kelompok Fauzah (2015). Berdasarkan Tabel 2 ditemukan bahwa siswa perempuan lebih banyak menjawab YA daripada TIDAK. Sebaliknya, siswa laki-laki lebih banyak menjawab TIDAK daripada YA. Berdasarkan hasil penelitian tersebut, dapat dinyatakan bahwa siswa perempuan lebih berpandangan positif dibandingkan siswa laki-laki terhadap penerapan pendekatan saintifik pada pembelajaran biologi materi Achaebacteria dan Eubacteria. Menurut Fauzah (2015) guru yang dapat menerapkan pendekatan saintifik yang sesuai dan tepat akan 
mampu menumbuhkan sikap positif dan meningkatkan hasil belajar siswa.

Hal ini menunjukkan bahwa penerapan pendekatan saintifik lebih dirasakan positif oleh siswa perempuan daripada siswa laki-laki Hal ini berbanding lurus dengan hasil kemampuan STEAM siswa perempuan yang lebih unggul dibandingkan siswa laki-laki. Menurut Baron dan Byrne (dalam Hoang 2008) menyatakan bahwa gender secara tidak langsung berpengaruh terhadap motivasi belajar dan hasil belajar, dimana siswa perempuan memiliki partisipasi dan cara belajar yang lebih aktif sehingga mampu memiliki hasil belajar yang lebih tinggi dibandingkan siswa laki-laki yang pasif dalam proses pembelajaran.

Buinicontro (2018) menyatakan bahwa pada pembaruan kurikulum 2013, disiplin ilmu yang mengintegrasikan STEAM menjadi sebuah pendekatan terpadu yang dapat diimplementasikan dalam pembelajaran di sekolah. Lebih lanjut Buinicontro (2018) menyatakan bahwa pendekatan saintifik sangat cocok untuk memadukan pembelajaran berbasis STEAM karena pembelajaran dilaksanakan dengan menggunakan berbagai konteks yang dapat mendekatkan materi pelajaran dengan kehidupan sehari-hari. Daryanto (2014) menyatakan bahwa pendekatan saintifik dalam pembelajaran meliputi pola $5 \mathrm{M}$ yaitu mengamati, menanya, menalar, mencoba, dan mengkomunikasikan yang membuat siswa dapat berpartisipasi dan terlibat secara aktif selama pembelajaran sehingga memacu keaktifan dalam berkomunikasi.

Kemampuan STEAM erat kaitannya dengan berkomunikasi yang baik, sehingga guru perlu mempehatikan kemampuan mengkomunikasikan yang dilakukan oleh siswa selama proses pembelajaran (Fadhilaturrahmi, 2017). Selain itu, Shadiq (2019) menyatakan sebagai akibat dari aplikasi industri 4.0 adalah ketimpangan yang semakin besar,sehingga tidak cukup memiliki skill berkomunikasi yang baik, tetapi juga harus memiliki aspek kreativitas dan berpikir kritis yang juga perlu diperhatikan oleh guru. Oleh karena itu, dalam upaya mengembangkan kemampuan berpikir tingkat tinggi sekaligus mengembangkan kreativitas, implementasi STEAM dalam pembelajaran menjadi sangat dibutuhkan.

\section{KESIMPULAN}

Terdapat perbedaan kemampuan STEAM pada materi Archaebacteria dan Eubacteria antara siswa perempuan dan siswa laki-laki. Kemampuan STEAM siswa perempuan diperoleh nilai rata-rata sebesar 70,60\%, sedangkan kemampuan STEAM siswa laki-laki diperoleh nilai rata-rata sebesar
53,00\%. Hal ini menunjukkan bahwa kemampuan STEAM siswa perempuan di SMAN 2 Percut Sei Tuan lebih tinggi dibandingkan siswa laki-laki. Pandangan siswa untuk pembelajaran biologi materi Achaebacteria dan Eubacteria dengan pendekatan saintifik kelas $X$ di SMAN 2 Percut Sei Tuan menunjukkan bahwa siswa perempuan lebih banyak menjawab YA dibandingkan siswa laki-laki. $\mathrm{Hal}$ ini membuktikan bahwasanya siswa perempuan lebih berpandangan positif dari pada siswa laki-laki terhadap penerapan pendekatan saintifik pada pembelajaran biologimateri Achaebacteria dan Eubacteria.

\section{DAFTAR PUSTAKA}

Apriliana, M. R., A. Ridwan., T. Hadinugrahaningsih., dan Y. Rahmawati. (2018). Pengembangan Soft Skills Peserta Didik melalui Integrasi Pendekatan Science, Technology, Engineering, Arts, and Mathematics (STEAM) dalam Pembelajaran Asam Basa. Jurnal Riset Pendidikan Kimia. 8(2): 42-51.

Amin, A., dan Suadirman, S.P. (2016). Perbedaan Prestasi Belajar Matematika Siswa Ditinjau dari Gaya Belajar dan Model Pembelajaran. Jurnal Prima Edukasia. 4(1):12-19.

Arikunto, S. (2005). Manajemen Penelitian. Jakarta: Rineka Cipta.

Aziz, R. dan Mangestuti, R. (2005). Tiga Jenis Kecerdasan dan Agresivitas Mahasiswa. Jurnal Psikologika. 21(11): 64-77.

Bastable, S.B. (2002). Perawat Sebagai Pendidik: Prinsip-prinsip Pengajaran dan Pembelajaran. Jakarta: EGC

Brizendine, L. (2006). Female Brain. New York: Morgan Road Books.

Buinicontro, J. K. (2018). Gathering STEAM: Policy, Curricular, and Programmatic Developments in Arts-Based Science, Technology, Engineering, and Mathematics Education Introduction to Special Issue of Art Education Policy Review: STEAM Focus. Art Education Policy Review Journal. 119(2):110-111.

Casey, M.B., Nuttall, R.L., Pezaris, E. (2001). Spatial Mechanical Reasoning Skills Versus Mathematics Self-Confidence as Mediators of Gender Differences on Mathematics Subtests Using Cross-National Gender-Based Items. Journal for Research in Mathematics Education. 32(1):29-56.

Cramond, B., Morgan, J.M., Bandalos, D., dan Zuo, L. (2005). A Report on the 40 year Follow Up of the Torrence tests of Creative Thingking: Alive and Well in the New Millenium. Gifted Child Quarterly. 49 (4): 283-291. 
Daryanto. (2014). PembelajaranTematik, Terpadu, Terintegrasi (Kurikulum 2013). Yogyakarta: Gava Media.

Elliot, S.N., Kratochwill, T.R., Cook, J.L., and Traves, J.F. (2000). Educational Psycologyl: Effective Teaching, Effective Learning, Third Edition. United States of Aeria: McGraw-Hill Companies, Inc.

Fadhilaturrahmi. (2017). Penerapan Pendekatan Saintifi untuk Meningkatkan Kemampuan Komunikasi Matematika Peseta Didik di Sekolah Dasar. Jurnal Pendidikan Dasar. 9(2): 109-118.

Fauzah, N. (2015). Persepsi Siswa terhadap Guru dalam Penggunaan Pendekatan Saintifik dan Pengaruhnya terhadap Hasil Belajar Biologi Materi Pokok Sistem Ekskresi Siswa Kelas XI IPA 2 SMA Negeri 1 Mijen Demak Tahun Ajaran 2014/2015. Skripsi. Universitas Islam Negeri Walisongo Semarang.

Firman, H. (2016). Pendidikan STEM sebagai Kerangka Inovasi Pembelajaran Kimia untuk Meningkatkan Daya Saing Bangsa dalam Era Masyarakat Ekonomi ASEAN. Prosiding Seminar Nasional Kimia dan Pembelajarannya, (September).

Handayani, C.S., dan Novianto, A. (2004). Kuasa Wanita Jawa. Yogyakarta: LkiS.

Handayani, S.S.L., Suciati,. dan Marjono. (2016). Peningkatan Keterampilan Proses Sains pada Pembelajaran Biologi Melalui Penerapan Model Bounded Inquiry Lab. Jurnal Bioedukasi. 9(2): 49-54.

Hasruddin., Harahap, F., dan Mahmud. (2018). Efektivitas Penerapan Perangkat Perkuliahan Mikrobiologi Berbasis Kontekstual terhadap Kemampuan Berpikir Tingkat Tinggi Mahasiswa Pendidikan Biologi Unimed. Jurnal Bioedukasi: Jurnal Pendidikan Biologi. 11(1): 51-54

Hoang, T.N. (2008). The Effect of Grade Level, Gender, and Ethnicity on Attitude and Learning Environment in Accounting in High School: International Electronic Journal of Accounting Educations. 3(1):82-89.

Kartono, K. (1989). Psikologi Wanita (Jilid 1): Mengenal Gadis Remaja dan Wanita Dewasa. Bandung: CV Mandar Maju.

Lestari, E., Arsila, P., Irawati, M., dan Hasruddin. (2019). Analisis Kemampuan Sains, Technology, Engineering, dan Matematics Berbasis Gender pada Materi Virus Siswa SMA Negeri 1 Tebingtinggi. Makalah disampaikan pada Seminar Nasional Biologi dan Pembelajarannya ke-5 Program Studi Pendidikan Biologi Pascasarjana Unimed. Medan: PPs Unimed.
Lestari, R.B. (2010). Pemberdayaan Wanita Melalui Teknologi Informasi (Sebuah Kajian Pustaka. Prosiding Seminar Nasional Aplikasi Teknologi Informasi. ISSN: 1907-5022.

Purwanti, K. L. (2013). Perbedaan Gender terhadap Kemampuan Berhitung Matematika Menggunakan Otak Kanan pada Siswa Kelas 1. Jurnal SAWWA. 9 (1): 107-122.

Rini, P. (2017). Efektivitas Model Problem Based Learning untuk Mereduksi Disparitas Gender dalam Capaian Pembelajaran Sains. Jurnal IImiah Pendidikan Fisika Al-Biruni, 6(1) https://doi.org/10.24042/ ipifalbiruni.v6i1.909

Salmina, M., dan Nisa, S.K. (2018). Kemampuan Penalaran Matematis Siswa Berdasarkan Gender pada Materi Geometri. Jurnal Numeracy. 5(1): 41-48.

Saraswati, E. (2015). Perbedaan Hasil Belajar Siswa Laki-laki dan Perempuan dalam Mata Pelajaran Matematika Kelas III Semester 2 Materi Sudut dan Pecahan di SD Negeri SeDesa Caturharjo, Kecamatan Sleman, Kabupaten Sleman. Skripsi. Universitas Negeri Yogyakarta.

Shadiq, F. (2019). Pembelajaran Matematika pada Era Industri 4.0. Suatu Tantangan Bagi Guru dan Pendidik Matematika. Prosiding pada Seminar Nasional Penelitian Pendidikan Matematika UMT.

Suhendra, Y. (2008). Perbandingan Gender dalam Prestasi Literasi Siswa Indonesia (Online). Tersedia pada: http://www.uninus.ac.id/PDF/Suhendra \%20Yusuf\%20\%20Makalah\%20untuk \%20Jurnal\%20Uninus.pdf. Diakses pada Tanggal 15 Februari 2020.

Surachman., Wibowo, Y., dan Suhardi. (2014). Implementasi Scientific Process pada Mata Pelajaran Biologi di MA Kotamadya Yogyakarta. Jurnal Pendidikan Matematika dan Sains Tahun II. 1(2):168-177.

Utomo, U. (2006). Gender dan Musik: Kajian tentang Konstruksi PeranLaki-laki dan Perempuan dalam Proses Pendidikan Musik. Harmonia Jurnal Pengetahuan dan PemikiranSeni. 7 (1):1-13.

Wahyudi. (2014). Penerapan Model Direct Instruction Terhadap Hasil Belajar Fisika Materi Pengukuran Ditinjau dari Gender pada Siswa. Program Studi Pendidikan Fisika IKIP PGRI Pontianak, 178-186.

YJP (Yayasan Jurnal Perempuan) Pendidikan Publik JP91. (2016). Status Perempuan dalam STEM. Sumatera Utara: USU. 